Tomasz Róg

Państwowa Wyższa Szkoła Zawodowa w Pile

\title{
POGLĄDY POLSKICH NAUCZYCIELI NA UŻYCIE JĘZYKA PIERWSZEGO W ROZWIJANIU OBCOJĘZYCZNEJ KOMPETENCJI KOMUNIKACYJNEJ
}

\begin{abstract}
Polish teachers' perceptions of the role of mother tongue in developing communicative competence in a foreign language

Although a dominating paradigm in foreign language teaching in the past decades has been to use foreign language as often as possible, voices are now being raised that there is a place for students' mother tongue in a language classroom. As the present article shows, both the critics and the supporters of the monolingual principle put forward commonsensical arguments in support of their stands. These arguments are outlined in the first part of the present article together with a brief look at the history of foreign-language-only approaches in language teaching methodology. What follows is a report on a study conducted by the author among 20 teachers in Poland with the aim of finding out the extent of and reasons for using mother tongue. The study demonstrated that on average teacher talking time in $60 \%$ comprises foreign language. Students' first language is primarily used for teaching grammar and translating vocabulary.
\end{abstract}

Keywords: first language, mother tongue, classroom interaction

Słowa kluczowe: język pierwszy, język ojczysty, komunikacja w klasie

\section{Wprowadzenie}

Rozważając techniki kształcenia i rozwijania podsystemów językowych w kształceniu obcojęzycznym, warto zastanowić się nad rolą, jaką pełnić może w tym procesie język ojczysty ucznia (i nauczyciela). Jak wynika z pobieżnego przeglądu 
literatury przedmiotu (o czym poniżej), kwestia użycia pierwszego języka ucznia w trakcie lekcji języka obcego nie doczekała się definitywnych rozstrzygnięć. Liczne badania nie przyniosły odpowiedzi na pytanie, czy dane językowe dostarczane uczniom przez nauczycieli powinny być wyłącznie w języku obcym, czy może użycie języka ojczystego usprawnia proces uczenia się języka obcego. Z jednej strony, przekonanie o konieczności używania przez nauczyciela wyłącznie języka docelowego ma zagorzałych zwolenników i wieloletnią tradycję w dydaktyce językowej. Zwolennicy takiego podejścia podkreślają konieczność ekspozycji ucznia na tzw. input językowy, bez którego nie może być mowy o późniejszej produkcji języka. Z drugiej strony, pojawiają się głosy, że język pierwszy ma swoje uzasadnione miejsce w nauce języka obcego. Przede wszystkim podkreśla się użycie tzw. technik bilingwalnych, ułatwiających komunikację z nauczycielem oraz redukujących stres językowy. Wiedza na temat korzyści i barier wynikających z nauczania monolingwalnego z pewnością przydaje się w klasie językowej, zwłaszcza wobec istnienia alternatywnych koncepcji opisujących i interpretujących wyniki badań nad rolą pierwszego języka w dydaktyce językowej. W niniejszym artykule autor przedstawi oba konkurujące stanowiska oraz przytoczy wyniki własnego badania dotyczącego użycia języka ojczystego w polskich szkołach. Celem przeprowadzonego badania było wskazanie, jak często język ojczysty ucznia pojawia się na lekcjach, na jakich etapach lekcji oraz jakie są wady i korzyści jego użycia w przekonaniu nauczycieli.

\section{Przegląd literatury}

Dwudziesty wiek, nazywany w glottodydaktyce wiekiem metod, przyniósł dwa skrajne podejścia do użycia języka pierwszego. Metoda gramatyczno-tłumaczeniowa i podejście Community Language Learning kładły silny nacisk na język ojczysty, który używany był do tłumaczenia słownictwa i udzielania wyjaśnień. Zdaniem badaczy takich jak J. Richards i T. Rogers (1986), wykluczenie języka pierwszego może prowadzić do wielu nieporozumień w klasie językowej, a wręcz do niemożności nauczenia języka obcego. $Z$ drugiej strony metody takie jak Metoda Bezpośrednia lub Natural Approach S. Krashena i T. Terrell (1983) wskazywały na możliwość uczenia języka obcego bez odwoływania się do języka ojczystego, zakładając, że towarzyszyć temu będzie odpowiednia demonstracja i odpowiednio dobrany język (comprehensible input). Oba te założenia postrzegały uczenie się języków obcych jako podobne do akwizycji pierwszego języka. Zarówno metoda gramatyczno-tłumaczeniowa jak i bezpośrednia miały swoje logiczne przesłanki. Ta pierwsza wskazywała na potencjalną możliwość złożenia języka jako całości, ta druga na możliwość sukcesu, ponieważ 
Poglądy polskich nauczycieli na użycie języka pierwszego w rozwijaniu...

zawsze odnosi go dziecko przyswajające swój pierwszy język, lub osoby przebywające dłużej w obcojęzycznym środowisku (patrz: Siek-Piskozub i Wach, 2006: 15). Inne metody, m.in. Metoda Audio-Lingwalna zabraniała użycia języka pierwszego w początkowych stadiach nauczania, ale pozwalała na jego użycie na wyższych poziomach zaawansowania (Rivers, 1981).

Wśród przeciwników użycia języka ojczystego dominuje pogląd, że język obcy powinien być nie tylko celem, ale również narzędziem nauczania. Najczęściej pojawiająca się opinia to taka, że bez inputu językowego nie może być produkcji językowej. W sytuacji gdy nauczyciel zbyt często odwołuje się do języka ojczystego, uczniowie tracą okazję "osłuchania się" z językiem. Jest to niekorzystne, zwłaszcza w sytuacjach, kiedy nauczyciel jest jedynym źródłem i modelem języka docelowego (Turnbull, 2001). Ograniczenie ekspozycji na język obcy, a w konsekwencji spowolnienie procesu uczenia się/ nabywania tego języka było przedmiotem wielu badań (m.in. Kharma i Hajjaj, 1989; Macdonald, 1993; Cook, 2001). S. Deller i M. Rinvolucri (2002) podkreślają, że stosowanie języka pierwszego powinno być ograniczone do minimum, a jego użycie usprawiedliwione tylko w trzech sytuacjach: do porównywania gramatyki dwóch języków, w przypadku uczniów początkujących (użycie języka ojczystego może przyspieszyć naukę języka obcego), oraz w przypadku tłumaczenia zdań, gdy dane zagadnienie gramatyczne nastręcza uczniom trudności. Założenie, że języka ojczystego należy unikać za wszelką cenę, ponieważ spowalnia on rozwój języka obcego, zostało niedawno opisane w pracy W. Littlewooda i B. Yu (2011). Często przywoływaną metaforą jest ta, że nie sposób nauczyć się pływać, nie wchodząc do wody. Ponadto, uważa się, że użycie języka pierwszego pozbawia uczniów cennego doświadczenia, jakim jest staranie się dotarcia do sensu tego, co słyszą (Ellis, 1994: 223).

Część badaczy postrzega użycie pierwszego języka uczniów w nauce języka obcego nie tylko jako coś naturalnego, ale również jako czynnik pozytywnie wpływający na proces nauki. E. Auerbach (1993: 19-23) podkreśla znaczenie pierwszego języka w utrzymywaniu dyscypliny klasowej, dyskusji nad problemami natury interkulturowej, udzielaniu instrukcji, wyjaśnianiu błędów i sprawdzaniu zrozumienia poleceń. Według przywołanej autorki, język pierwszy zapewnia uczniom poczucie bezpieczeństwa, co ma wpływ na chęć eksperymentowania i podejmowania ryzyka w języku obcym. E. Macaro (1997) zwraca uwagę na fakt, że język pierwszy stanowi naturalne narzędzie wspierające zarówno nauczyciela jak i uczniów w czasie lekcji języka obcego. Inni badacze podkreślają wagę języka pierwszego w redukowaniu stresu językowego, pomaganiu uczniom zrozumieć stawiane przez nauczyciela wymagania oraz w nauczaniu języka obcego poprzez zwiększanie świadomości różnic pomiędzy dwoma językami (Eldridge, 1996; Schweer, 1999). W trakcie konferencji 
TESOL w 1997 r. T. Doyle przyznał, że w czasie jego zajęć blisko 90\% lekcji odbywa się w języku ojczystym i dodał, że 65\% uczniów woli używać języka pierwszego podczas nauki.

Ostatnie dekady, zwłaszcza począwszy od podejścia komunikacyjnego w dydaktyce języków obcych, charakteryzował silny zwrot w stronę klas monolingwalnych, czyli takich, gdzie używa się tylko jednego języka (docelowego). Jak piszą W. Butzkamm i J. Caldwell (2009: 24), zasada jednojęzyczności stała się branym za pewnik dogmatem w klasach językowych, a użycie wyłącznie języka obcego w czasie lekcji punktem honoru dla wielu nauczycieli. Kwestia odwoływania się do języka ojczystego była z kolei tematem tabu oraz źródłem wstydu i poczucia winy dla nauczycieli niepodporządkowujących się trendowi (Prodromou, 2002: 6). Dominujące przekonanie o ograniczającej funkcji języka ojczystego prowadziło do zarzucenia podejścia porównawczego, a użycie tłumaczeń w klasie językowej postrzegane było negatywnie. Metoda bezpośrednia, zdaniem W. Butzkamma (2003: 29), odnosiła triumfy pod szyldem podejścia komunikacyjnego, a efektywne techniki nauczania bilingwalnego były praktycznie nieznane.

Dominujący współcześnie paradygmat jednojęzyczności w klasie językowej bywa kwestionowany przez badaczy (zwłaszcza: Butzkamm, 2003; Butzkamm i Caldwell, 2009; Swain, Kirkpatrick i Cummins, 2011). V. Cook (2001: 404) zwraca uwagę, że pomimo powszechnego przekonania o konieczności porozumiewania się z uczniami wyłącznie w języku docelowym, nie ma żadnego jasnego teoretycznego uzasadnienia, dlaczego taka praktyka miałaby być właściwa. W. Butzkamm i J. Caldwell (2009: 24) twierdzą wręcz, że język ojczysty jest największym sprzymierzeńcem uczących się języka obcego. Ponieważ języka "uczymy się tylko raz” (Butzkamm i Caldwell, 2009: 66), każdy następny język musi być skonfrontowany z tym pierwszym. Powołując się na własne doświadczenia, W. Butzkamm (2003: 30) przywołuje relacje nauczycieli języków obcych, którzy sami podejmują naukę kolejnych języków i uświadamiają sobie, że najbardziej potrzeba im tego, czego sami odmawiają swoim uczniom. I tak, nauczycielka języka angielskiego opisuje swoje doświadczenia jako uczennica języka greckiego: nie jest zadowolona z tego, że musi „rozumieć ogólnie"; wolałaby rozumieć każde słowo. Ponadto uważa, że tłumaczenie tekstów jest dobrą praktyką, bo daje możliwość pracy ze słownikiem (McDonough 2002: 405 za Butzkamm, 2003).

Zdaniem V. Cook (2002) nie ma żadnej „rywalizacji” pomiędzy pierwszym a kolejnymi językami. Każdy uczący się nowego języka posiada istniejącą już bazę języka pierwszego, więc użycie jednego nie stanowi zagrożenia dla drugiego. Ponadto, sam fakt posiadania pierwszego języka świadczy o większej pojemności pamięci krótkotrwałej, większej dojrzałości społecznej i lepszej 
gotowości do uczenia się kolejnego języka. Zauważono też, że języki w mózgu nie tworzą odrębnych podsystemów, ale są powiązane ze sobą na poziomie fonologii, morfosyntaksy i semantyki (Chłopek, 2011: 50). Stąd, nauczanie języków obcych nie musi być odizolowywane od języka ojczystego. Jak zwraca dodatkowo uwagę T.Timor (2012: 9) proces uczenia się języka obcego łączy się z czynnikami poznawczymi, społecznymi i emocjonalnymi, które są powiązane w równym stopniu z językiem obcym co ojczystym.

W. Butzkamm (2003) wysuwa szereg postulatów i argumentów, dlaczego wykorzystanie pierwszego języka uczniów jest tak istotne. Przede wszystkim nie sposób „wyłączyć" języka ojczystego, stąd transfer językowy i próba tłumaczenia będą naturalnymi zjawiskami. Pomimo różnorodnych technik prezentacji nowego słownictwa i użycia pomocy dydaktycznych, uczniowie nie rozumieją więcej, niż to się wydaje nauczycielom (Butzkamm, 2003: 30). W badaniach, gdzie sprawdzano rozumienie znaczeń na koniec lekcji, okazało się, że wielu uczniów błędnie zinterpretowało znaczenie większości słów (Butzkamm, 2003: 60). Zdaniem cytowanego autora, "nowe” należy kojarzyć ze "starym", a zatem podobnie jak to postuluje konstruktywizm, odwoływać się do już istniejącej wiedzy. Niestety, nauczyciele nie są przygotowani do używania technik bilingwalnych, czyli takich, które pomagają uczyć języka obcego odwołując się do języka ojczystego.

\section{Badanie własne}

Na podstawie zreferowanych powyżej wyników badań nad użyciem języka pierwszego w klasie językowej, postanowiono zbadać podejście polskich nauczycieli do wykorzystania języka ojczystego uczniów na lekcji języka obcego. W tym celu, autor artykułu przeprowadził badanie wśród nauczycieli języków obcych różnych typów szkół z rejonu Wielkopolski. Głównym celem badania sondażowego było znalezienie odpowiedzi na pytania: jak często język pierwszy pojawia się w czasie lekcji i jaki jest stosunek nauczycieli do jego użycia.

\subsection{Narzędzia i przebieg badania}

W celu zbadania częstotliwości użycia języka pierwszego na lekcji oraz ustalenia w jakich sytuacjach jest on używany i dlaczego, autor poprosił wybranych nauczycieli o wypełnienie ankiety. Wśród nauczycieli, do których skierowano tę prośbę znaleźli się przede wszystkim byli i obecni współpracownicy autora, nauczyciele znani z konferencji, szkoleń metodycznych i konkursów przedmiotowych. Autor poprosił ich również o wskazanie innych nauczycieli, którzy mogliby 
wziąć udział w badaniu. W ten sposób, ankieta dotarła do 90 nauczycieli z rejonu całej Wielkopolski (od powiatu krotoszyńskiego po złotowski), przy czym odpowiedzi zwróciło jedynie 20 nauczycieli. Ankieta składała się z ośmiu pytań, dwa pierwsze dotyczyły płci i stażu pracy w zawodzie nauczyciela języka obcego. W kolejnych pytaniach, autor pytał o częstotliwość użycia języka obcego na lekcji (z prośbą o wskazanie stopnia zaawansowania uczniów), sytuacje, w których nauczyciel odwołuje się do języka pierwszego, powody tych odwołań oraz wady i zalety użycia języka pierwszego na lekcji.

W badaniu wzięło udział dwudziestu nauczycieli języków obcych (przede wszystkim języka angielskiego, ale również języka niemieckiego), 16 kobiet i czterech mężczyzn. Wśród nich najkrótszy staż pracy to 2 miesiące, a najdłuższy 25 lat. Średni staż pracy badanych (odrzucając dwa skrajne wyniki) to 9 lat.

\subsection{Wyniki ankiety}

W pierwszym pytaniu ankietowym, badani zostali poproszeni o oszacowanie, jaki procent ich lekcji odbywa się w języku obcym. Dodatkowo, mieli wskazać, na jakich poziomach zaawansowania uczą i czy ilość użytego języka obcego różni się w zależności od poziomu. Wyniki zaprezentowano w tabeli 1.

\begin{tabular}{|l|c|}
\hline Poziom zaawansowania językowego & Liczba osób \\
\hline przedszkole & $80 \%$ (jedna taka odpowiedź) \\
\hline początkujący & $50,33 \%$ \\
\hline średniozaawansowany & $62,83 \%$ \\
\hline zaawansowany & $70,71 \%$ \\
\hline bez wskazania poziomu & $46 \%$ \\
\hline
\end{tabular}

Tabela 1: Proszę oszacować, w ilu procentach używa Pani/ Pan języka obcego w czasie lekcji.

Jedna z badanych osób wskazała, że na tym samym poziomie (średniozaawansowanym) używa języka obcego w 60\% czasu lekcji w szkole ponadgimnazjalnej, ale w 90\%, gdy uczy w szkole prywatnej.

W następnym pytaniu, proszono o podanie sytuacji, w których język polski używany jest na lekcji języka obcego. Wyniki przedstawia tabela 2.

\begin{tabular}{|l|c|}
\hline W jakich sytuacjach używa Pani/Pan języka ojczystego? & Średni wynik procentowy \\
\hline wyjaśnianie gramatyki & $95 \%$ \\
\hline tłumaczenie niezrozumiałych słów & $80 \%$ \\
\hline dyscyplinowanie uczniów & $25 \%$ \\
\hline wydawanie poleceń & $20 \%$ \\
\hline lekcje kulturowe/ ocenianie/ chwalenie uczniów & $5 \%$ \\
\hline
\end{tabular}

Tabela 2: Sytuacje, w których nauczyciele odwołują się do języka ojczystego. 
Poglądy polskich nauczycieli na użycie języka pierwszego w rozwijaniu...

Kolejne pytanie dotyczyło sytuacji, w których nauczyciele mówią do uczniów w języku obcym. Proszono o wymienienie, w jakich momentach w czasie lekcji używa się wyłącznie języka obcego.

\begin{tabular}{|l|c|}
\hline $\begin{array}{l}\text { W jakich sytuacjach mówi Pani/ Pan do uczniów wyłącznie } \\
\text { w języku obcym? }\end{array}$ & Średni wynik procentowy \\
\hline wydawanie poleceń & $55 \%$ \\
\hline przez większość czasu & $45 \%$ \\
\hline powitanie/ pożegnanie & $25 \%$ \\
\hline zadawanie uczniom pytań & $20 \%$ \\
\hline wyjaśnianie gramatyki & $10 \%$ \\
\hline $\begin{array}{l}\text { rozmowa na podstawie tekstu lub obrazka; udzielanie } \\
\text { pochwał; poprawa błędów; podawanie definicji słów }\end{array}$ & $5 \%$ \\
\hline
\end{tabular}

Tabela 3: Sytuacje, w których nauczyciele mówią do uczniów w języku obcym.

W kolejnym pytaniu, badani wskazywali na powody rezygnacji z języka obcego. Do wyboru było 6 opcji: Nie mówię płynnie w języku obcym; Uczniowie nie rozumieją, co do nich mówię; Mówienie bez przerwy w jęz. Obcym męczy mnie; Chcę się upewnić, że uczniowie dobrze zrozumieli; Nie umiem wytłumaczyć wszystkiego w języku obcym; W języku ojczystym łatwiej mi nawiązać kontakt z uczniami. Była też możliwość wpisania własnej odpowiedzi. W przypadku tego pytania, najczęściej pojawiającą się odpowiedzią było: "Chcę się upewnić, że uczniowie dobrze zrozumieli" - 80\% odpowiedzi oraz „Uczniowie nie rozumieją, co do nich mówię" - 75\% wskazań. Dwadzieścia procent badanych wybrało również opcję, że w języku ojczystym łatwiej im nawiązać kontakt z uczniami. Dwoje nauczycieli postanowiło udzielić własnych odpowiedzi: „Gdy wyjaśniam gramatykę, chcę mieć pewność, że uczniowie rozumieją”, „Uczę w klasach najmłodszych, nie zawsze mimo najszczerszych chęci, dzieci rozumieją co chcę im przekazać w obcym języku".

W siódmym pytaniu, badani mieli za zadanie wskazać zalety użycia języka ojczystego. Wśród wielu odpowiedzi, najczęściej pojawiającymi odpowiedziami były: „lepsze zrozumienie tego, co mówię”, „uczniowie lepiej rozumieją gramatykę”, „uczniowie lepiej rozumieją polecenia” i „łatwiej nawiązać kontakt z uczniami". Pojedyncze odpowiedzi dotyczyły przełamania niechęci do języka obcego, zmniejszenie stresu i zwiększenie tempa lekcji. Jedna z nauczycielek podała, że nie widzi żadnych zalet. Pojawiły się też inne ciekawe spostrzeżenia, których fragmenty przytoczone są poniżej:

„Uczniów czasami stresuje nadmiar angielskiego i to ich zniechęca”.

„Język ojczysty pozwala na lepsze zrozumienie danego zagadnienia przez uczniów oraz przyswojenie i zrozumienie przez nich różnych instrukcji, które na egzaminie końcowym również są podawane w języku ojczystym”. 
„W grupach o zróżnicowanym poziomie prowadzenie dwujęzyczne daje mi poczucie, że zrobiłam wszystko, by uczniowie zrozumieli polecenia, zadanie domowe, typy zadań m.in. na maturze, kruczki egzaminacyjne - tym bardziej, że polecenia na maturze są w języku ojczystym".

„Umożliwia kontakt nawet z uczniami o najniższym stopniu zaawansowania”. „Czasem bywa tak, że po ciężkim materiale następuje rozluźnienie chwilowe i pozwalam im na to, na jakiś żarcik, pośmianie się. Mam wtedy lepszy kontakt z uczniami, oni poznają również mnie. Myślę, że można to jako umocnienie więzi nazwać".

Ostatnie pytanie dotyczyło wad użycia języka ojczystego na lekcji języka obcego. Połowa badanych podkreślała, że użycie języka polskiego oznacza mniej „osłuchania” z językiem obcym. Wskazywano również na problem przyzwyczajania się uczniów do używania języka ojczystego na lekcji oraz ciągłe porównywanie dwóch języków, a także brak modelu, rozleniwienie umysłowe uczniów i mniejszą ilość przekazywanego słownictwa.

Ponadto, zebrano warte przytoczenia spostrzeżenia pojedynczych nauczycieli:

"Mam poczucie winy, gdy używam języka polskiego".

„Jeżeli lekcja dotyczy ćwiczenia słownictwa, lepiej jest mówić prawie wyłącznie w języku obcym, gdyż dziecko poprzez osłuchanie się z językiem obcym ma szansę zacząć mówić $w$ tym języku. Natomiast z doświadczenia wiem, że przyswajanie przez uczniów gramatyki zdecydowanie lepiej odbywa się, jeśli używany jest język ojczysty".

„W trakcie lekcji języka obcego uczniowie powinni jednak słyszeć jak najwięcej języka obcego, aby się z nim osłuchać, niektórzy z nich nie mają poza lekcją żadnego kontaktu z językiem obcym".

„Poprzez użycie jęz. ojczystego nie tworzy się całkowicie 'atmosfery obcojęzycznej' w klasie".

"Celem nauczania j. obcego jest komunikacja w tym języku, a nie w ojczystym" „Uczniowie tracą poczucie realności języka obcego".

\subsection{Wnioski}

Badana grupa składała się z 20 nauczycieli i nie może ona stanowić grupy reprezentatywnej. W wyniku zaistniałej sytuacji (tj. niereprezentatywna liczba probantów) przedstawione badanie należy zatem potraktować jako pilotażowe. W jego toku zarysowano stosunek nauczycieli języków obcych do użycia języka ojczystego w Polsce oraz uzyskano szacunkowe dane na temat częstości używania języka obcego w czasie lekcji. Głównym celem badania nie było jednak przedstawienie statystycznych zależności, ale zasygnalizowanie problemu. Mówienie z kolei o problemie nie jest przesadą, bowiem jak wynika 
Poglądy polskich nauczycieli na użycie języka pierwszego w rozwijaniu...

z przeglądu literatury na wstępie artykułu i z wypowiedzi badanych nauczycieli, użycie języka pierwszego na lekcji bywa dla nauczycieli sprawą kłopotliwą, wstydliwą i rodzącą poczucie winy (jak to określiła jedna z badanych). Z jednej strony, teoria wyniesiona ze studiów nauczycielskich i dominujące nadal podejście komunikacyjne kładzie nacisk na prowadzenie zajęć monolingwalnych, z drugiej strony nauczyciele często znajdują się w takich sytuacjach na lekcji, kiedy wsparcie się językiem ojczystym ułatwia komunikowanie treści, pozwala zaoszczędzić czas i usprawnia proces nauczania. Decyzje dotyczące tego kiedy i w jakiej ilości użyć języka ojczystego nie są dla nauczycieli łatwe.

Jak pokazują odpowiedzi na pierwsze pytanie, użycie języka obcego w trakcie lekcji zwiększa się wraz z poziomem zaawansowania. Innymi słowy, im bieglej uczniowie posługują się językiem, tym więcej danych językowych dostarczają im nauczyciele. W grupach początkujących średnio połowa zajęć odbywa się w języku obcym. Badanie pokazało, że na kolejnych poziomach (średnio- i zaawansowanym) ilość ta wzrasta przeciętnie o $10 \%$ na poziom. Jedna z badanych osób, pracująca w przedszkolu zaznaczyła, że używa języka angielskiego w 80 procentach lekcji. Staż pracy nauczycieli w zawodzie okazał się być niezwiązany z ilością użycia języka obcego (nauczycielka z 25-letnim stażem używała języka obcego średnio przez 30\% lekcji, a nauczycielka pracująca w zawodzie od dwóch miesięcy przez 70\%). Co ciekawe, jedna z badanych przyznała, że w języku obcym mówi częściej w prywatnej szkole językowej.

Jak wynika z badania, język pierwszy uczniów używany jest przede wszystkim do wyjaśniania reguł gramatycznych, niezależnie od poziomu językowego grupy. Drugą sytuacją, w której nauczyciele odwoływali się do języka ojczystego było tłumaczenie niezrozumiałych słów. Tylko jedna badana podawała definicje w języku obcym. Niepokojące wydaje się rzadkie (nieco ponad połowa badanych) użycie języka obcego do wydawania poleceń, kiedy to zachodzi szansa na autentyczną komunikację. Podobnie, użycie języka w funkcji interpersonalnej jest także rzeczywistą komunikacją. Tymczasem, nauczyciele w takich sytuacjach odwołują się do języka ojczystego. Uwagę na ten problem zwróciła wcześniej A. Niżegorodcew (2012: 161): „[nie]rodzimi nauczyciele często przechodzą na język ojczysty, gdy zmieniają funkcję dyskursu edukacyjnego (...) na rzeczywistą komunikację". Mniej niż połowa badanych twierdziła, że mówi do uczniów w języku obcym „przez większość czasu”.

Zakładając, że nauczyciele mówią do uczniów przez ok. 65\% lekcji (takie szacunki podaje C. Chaudron (1988: 51-54) powołując się na inne badania, m.in. (Bialystock i in., 1978; Legarret, 1977 i Enright, 1984). W innym badaniu E. Yefremova i in. (2012) podają, że nauczyciele średnio mówią przez 39\% czasu lekcji), w trakcie przeciętnej 45-minutowej lekcji, uczniowie mają tak naprawdę szansę słyszeć język obcy przez ok. 17 minut (tj. 60\% całego czasu, 
w którym mówi nauczyciel). Pozostaje zapytać jak często uczniowie mają lekcje, czy mają inny kontakt z językiem obcym i czy w istocie słuchają aktywnie. Inną kwestią, wartą zbadania, jest to, ile mają okazji do samodzielnego tworzenia wypowiedzeń w języku obcym

Badani nauczyciele wskazywali, że rezygnują z użycia języka obcego w sytuacjach, kiedy chcą się upewnić, czy uczniowie dobrze zrozumieli daną kwestię oraz kiedy uczniowie dają do zrozumienia, że nie rozumieją tego, co mówią nauczyciele. Mówiąc o zaletach użycia języka ojczystego, nauczyciele zauważali, że pozwala ono zwiększyć tempo lekcji, zmniejszyć stres uczniów, zrozumieć lepiej zasady gramatyczne i nawiązać lepsze relacje interpersonalne z uczniami. Co istotne, język polski używany jest w poleceniach na egzaminach zewnętrznych; część nauczycieli zwracała uwagę na konieczność odwołania się do języka polskiego choćby po to, by wyjaśnić treść zadań. Za główną wadę użycia języka ojczystego, nauczyciele uznali mniej szans na input językowy, a niektórzy wskazywali również na „rozleniwienie” uczniów i fakt, że przyzwyczajają się oni do użycia języka polskiego, kiedy nie chce im się analizować wypowiedzi w języku obcym.

\section{Zakończenie}

Zupełne wykluczenie języka pierwszego ucznia wydaje się być niemożliwe do wykonania, przede wszystkim ze względu na naturalną tendencję do używania go jako pierwszego punktu odniesienia. Nauczyciel nie jest przecież w stanie zabronić uczniom myślenia w ich ojczystym języku. Użycie pierwszego języka winno być jednak ograniczone do sytuacji, w których dalsze używanie języka obcego przez nauczyciela prowadzi do nieporozumień i rodzi frustrację uczniów, którzy nie są w stanie odczytać intencji wypowiedzi. Zwykle język pierwszy używany jest do wyjaśniania pojęć, klaryfikacji poleceń i omawiania strategii uczenia się, w przeciwnym razie użycie języka ojczystego wydaje się być nieuzasadnione.

Przedstawione w niniejszym artykule wyniki badań, zarówno własne, jak i studia literaturowe, świadczą o kłopocie nauczycieli języków obcych, borykających się z problemem użycia pierwszego języka uczniów na lekcji. Wśród zmiennych decydujących o częstości odwoływania się do niego wyróżnić należy przede wszystkim stopień zaawansowania językowego uczniów i ćwiczony podsystem językowy. Im wyższy poziom biegłości uczniów, tym częściej nauczyciele używają języka obcego; język pierwszy z kolei używany jest najczęściej podczas omawiania zagadnień gramatycznych. 


\section{BIBLIOGRAFIA}

Auerbach, E. 1993. «Reexamining English only in the ESL classroom». TESOL Quarterly 27(1): 9-32.

Butzkamm, W. 2003. "We only learn language once. The role of the mother tongues in FL classrooms: death of a dogma». Language Learning Journal 28(1): 29-39.

Butzkamm, W., Caldwell, J. 2009. The bilingual reform: a paradigm shift in foreign language teaching. Tübingen: Narr.

Chaudron, C. 1988. Second language classrooms. Research on teaching and learning. Cambridge: Cambridge University Press.

Chłopek, Z. 2011. Nabywanie języków trzecich i kolejnych oraz wielojęzyczność. Wrocław: Wydawnictwo Uniwersytetu Wrocławskiego.

Cook, C. 2001. Second language learning and language teaching. London: Hodder Arnold. Cook, V.J. 2001. "Using the first language in the classroom». Canadian Modern Language Review 57(3): 402-423.

Deller, S., Rinvolucri, M. 2002. Using the Mother Tongue. Peaslake: Delta Publishing. Doyle, T. 1997. The L1's role in ESL instruction, TESOL '97, Orlando.

Eldridge, J. 1996. "Code-switching in a Turkish secondary school». ELT Journal 50(14): 303-311.

Ellis, R. 1994. The study of second language acquisition. Oxford: Oxford University Press. Kharma, N. N., Hajjaj, A. H. 1989. "Use of the mother tongue in the ESL classroom». International Review of Applied Linguistics 27: 223-235.

Krashen, S. D., Terrell, T.D. 1983. The natural approach: language acquisition in the classroom. Oxford: Pergamon.

Littlewood, W., Yu, B. 2011. "First language and target language in the foreign language classroom ». Language Teaching 44(1): 64-77.

Macaro, E. 1997. Target language, collaborative learning, and autonomy. Clevendon: Multilingual Matters.

Macdonald, C. 1993. Using the target language. Cheltenham: Mary Glasgow Publications. Mcdonough, J. 2002. "The teacher as language learner: worlds of difference? ». English Language Teaching Journal 56 (4): 404-411.

Niżegorodcew, A. 2012. «Autentyczna komunikacja w dyskursie edukacyjnym: rola języka nauczanego i ojczystego». Neofilolog 38/2: 151- 163.

Richards, J. C., Rodgers, T.S. 1986. Approaches and methods in language teaching. Cambridge: Cambridge University Press.

Rivers, W. M. 1981. Teaching foreign language skills. Chicago: University of Chicago Press. Schweer, W. J. 1999. "Using L1 in the L2 classroom». English Teaching Forum 37(2): 6-9.

Siek-Piskozub, T., Wach, A. 2006. Muzyka i słowa. Rola piosenki w procesie przyswajania języka obcego. Poznań: Wydawnictwo Naukowe UAM.

Swain, M., A. Kirkpatrick i Cummins, J. 2011. How to have a guilt-free life using Cantonese in the English class: A handbook for the English language teacher in Hong Kong. Hong Kong. Research Centre into Language Acquisition and Education in Multilingual Societies, Hong Kong Institute of Education. 
Timor, T. 2012. "Use of the mother tongue in teaching a foreign language». Language Education in Asia 3(1): 7-17.

Turnbull, M. 2001. "There is a role for the L1 in second and foreign language teaching, but?». The Canadian Modern Language Review 57(4): 531-535.

Yefremova, E.P., S. V. Ruzhova i Kokorina, S.V. 2012. "The study of teacher talk time in the foreign language classroom». Teaching Science 9: 342-346. 